\title{
A NEW GENE FOR DEAFNESS IN THE MOUSE
}

\author{
M. S. DEOL and W. KOCHER \\ Medical Research Council Group for Experimental Research in \\ Inherited Diseases, University College, London
}

Received 22.i.58

Two years ago Deol (1956) reported the first case of inherited deafness in the mouse not associated with any of the usual concomitant locomotor disturbances. It was followed by a systematic search of the mouse colony of this laboratory, which resulted in the discovery of several other cases of the same kind. The mutant gene described here is one of them. The name deafness, symbol $d n$, is proposed for it.

\section{HEARING ABILITY AND BEHAVIOUR}

Hearing ability was tested by means of a click produced by striking a pair of forceps on a bottle. Refined methods were considered unnecessary as deafness could be recognised by this test without ambiguity in adult animals. Normal mice respond to it with a general muscular twitch which is most noticeable in the ear pinna. No such response was ever obtained in mice homozygous for deafness. The heterozygotes on the other hand were always normal, and the onset of hearing took place between Io and 14 days depending on the size, general fitness and, perhaps, the genetic constitution of the individual. A number of the heterozygotes were kept until they were well over a year old and their hearing ability was found to be unimpaired.

Though in general the behaviour of $d n / d n$ is normal, tossing movements of the head have been observed in some individuals. This is a barely perceptible abnormality and can be best described as an accentuation of the normal sniffling movements. But it is quite distinct from the latter, especially to an observer familiar with the mutants of the shaker-waltzer type.

\section{GENETICS}

The mutant gene $d n$ was discovered in the curly-tail stock of this laboratory, its origin being independent of the $c t$ gene. It must have been in that stock for some time as it was already fairly widely spread when first detected. The segregation data of table I show a close approximation to the ratios expected, if $d n$ is a recessive gene with regular manifestation.

It seems that the presence or absence of head tossing (HT) is influenced by the residual genotype. The data of table 2 show that, in matings between two $d n / d n$ animals, the incidence of head tossing is lowest when neither parent, and highest when both parents toss their heads $\left(\chi^{2}=8.5\right.$ II $\left.; n=2 ; \mathrm{P}=0.015\right)$. 
The double heterozygotes

$$
\begin{aligned}
& +/ d n ;+/ d f \\
& +/ d n ;+/ s h-\mathrm{I} \\
& +/ d n ;+/ s h-2 \\
& +/ d n ;+/ v \\
& +/ d n ;+/ j e \\
& +/ d n ;+/ p i
\end{aligned}
$$

\begin{tabular}{|c|c|c|c|c|}
\hline Mating & & Normal & Deaf & Total \\
\hline $\begin{array}{l}+1+\times d n / d n \\
d n / d n \times d n / d n \\
+\mid d n \times+/ d n \\
+\mid d n \times d n / d n .\end{array}$ & $\begin{array}{ll}\cdot & \cdot \\
\cdot & \cdot \\
\cdot & \cdot \\
. & .\end{array}$ & $\begin{array}{c}33 \\
\cdots \\
144 \\
6 \mathrm{I}\end{array}$ & $\begin{array}{r}\ldots \\
218 \\
57 \\
6 \mathrm{I}\end{array}$ & $\begin{array}{r}33 \\
218 \\
201 \\
122\end{array}$ \\
\hline
\end{tabular}

all show normal behaviour and can hear. In the case of $d n$ and $d f$, this has been followed to the age of 8 months, in the other cases for

\begin{tabular}{|c|c|c|c|c|}
\hline Mating & Normal (N) & $\begin{array}{l}\text { Head tossing } \\
(\mathrm{HT})\end{array}$ & $n$ & Per cent. HT \\
\hline $\mathrm{N} \times \mathrm{N}$ & $5^{2}$ & 2 & 54 & $3 \cdot 7$ \\
\hline $\mathrm{N} \times \mathrm{HT}$ & 16 & 3 & 19 & ${ }_{15} \cdot 8$ \\
\hline $\mathrm{HT} \times \mathrm{HT}$ & 12 & 5 & 17 & $29 \cdot 4$ \\
\hline
\end{tabular}

TABLE I

Segregation of $\mathrm{dn}$

TABLE 2

Incidence of head tossing $(H \mathcal{T})$ in $\mathrm{dn} / \mathrm{dn}$ animals

shorter periods. It thus appears that $d n$ is not an allel of any of these genes. A test of $d n$ against $V a$ has not yet been carried out. A test of $d n$ against the genes for $k r, d r$ and $f i$ was not considered necessary in view of the totally different pathological situation.

\section{HISTOLOGY}

The same technique was used as has been described by Deol (1954). It must be mentioned here that the embedding time for $56^{\circ} \mathrm{C}$. paraffin was given only vaguely in that publication. It should be put at one hour. If harder paraffins are to be used, the embedding time must presumably be even more reduced (say 45 minutes for $60^{\circ} \mathrm{C}$. paraffin).

Serial sections of the labyrinths of 35 mice were cut, some at $7 \frac{1}{2} \mu$ and some at ro $\mu$. The age of the mice ranged from 9 to 388 days (one-day-intervals between 9-I 5-day stages, longer intervals later on). Only a few of the normal controls were taken from the deafness stock; 
the rest came from previous investigations. In addition series of the sacculi of normal and head-tossing animals, about one year old, were cut (see table 3).

The pathological changes observed in the cochlea of $d n / d n$ mice closely resemble those of $d f / d f$ mice and indeed those of the degenerative group of mutants of the shaker-waltzer type (waltzer, shaker-I, shaker-2, jerker, pirouette and varitint-waddler). The earliest abnormalities of the organ of Corti appear at the age of io days when Deiters's cells begin to lose their identity: first their boundaries become indistinct and then the nuclei move to different levels. First changes in the hair cells can be clearly seen on the $15^{\text {th }}$ day. Abnormalities of the stria vascularis can be detected from the ioth day

TABLE 3

Histological anomalies of the macule sacculi

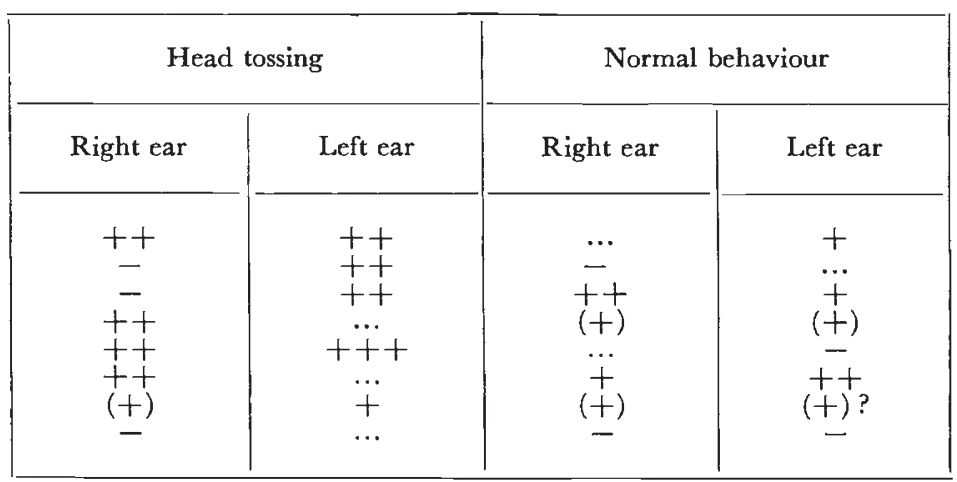

onwards. The free end of the tectorial membrane does not lie over the hair cells but curls up. When a $d n / d n$ mouse is about three weeks old most of the elements of the scala media complex are well on their way to degeneration, but the degeneration of the spiral ganglion does not seem to begin until about 50 days. This may be due to the difficulties involved in detecting any but gross pathological changes in the ganglion cells. In old mice, that is, 9 months or over, the degeneration of Corti's organ as well as the spiral ganglion is nearly complete. At this stage Corti's organ is a mass of dedifferentiated cells though the tunnel of Corti does not usually collapse (sometimes one or both rods may be missing), and the spiral ganglion has only a few remnants of the nerve cells left.

Degeneration of the macula of the sacculus was observed in headtossing as well as in normally behaving $d n / d n$ mice. In general it is of the same kind as is found in the shaker-waltzer group (Deol, 1954). Table 3 shows the degree of degeneration of the available maculæ sacculi. Normal maculæ are denoted by $-;(+)$ means that only a few hair cells are histologically abnormal. In severe cases (indicated $++)$ the hair cells degenerate completely and the otolith membrane 
comes to rest on the supporting cells. In some mice the otolith membrane may degenerate and the otoliths be lost. In one case (shown by +++ ) virtually the whole macula has disappeared.

Histological anomalies of the maculæ sacculi thus occur both in head-tossing and in normally behaving $d n / d n$ mice though the former perhaps tend to be more strongly affected. Obviously, slight anomalies of the macula are compatible with normal behaviour. Whether more extreme lesions are responsible for head tossing must remain an open question.

\section{SUMMARY}

I. A new recessive gene for uncomplicated deafness has been discovered ; the name deafness, symbol $d n$, is proposed for it.

2. As judged by a simple test, $d n / d n$ mice cannot hear at any time of their life while the hearing ability of the heterozygotes is unaffected.

3. Slight head tossing occurs in some $d n / d n$ mice. Its incidence is influenced by the residual genotype.

4. Beginning about the Ioth day, degeneration of the cochlear elements occurs in the homozygotes.

5. Degeneration of the macula of the sacculus may occur both in head tossing and in normally behaving mice, though some ears remain histologically normal even in old animals. The time of onset of the macular degeneration is not known.

Acknowledgments.-The authors are indebted to Prof. H. Grüneberg, F.R.s., for his interest, to Dr G. M. Truslove for help in many ways and to Dr C. A. B. Smith for statistical advice. The work was supported by a grant from the Rockefeller Foundation which is gratefully acknowledged.

\section{REFERENCES}

DEOL, M. S. I954. The anomalies of the labyrinth of the mutants Varitint-waddler, shaker-2 and jerker in the mouse. F. Genet., 52, 562-588.

DEOL, M. s. 1956. A gene for uncomplicated deafness in the mouse. F. Embryol. exp. Morph., 4, I90-195. 